\title{
Commentary: Anthropogenic disturbances jeopardize biodiversity conservation within tropical rainforest reserves
}

\author{
Víctor Arroyo-Rodriguez ${ }^{1 *}$ and Felipe P. L. Melo ${ }^{2}$ \\ ${ }^{1}$ Instituto de Investigaciones en Ecosistemas y Sustentabilidad, Universidad Nacional Autónoma de México, Morelia, Mexico, \\ ${ }^{2}$ Departamento de Botânica, Universidade Federal de Pernambuco, Recife, Brazil
}

Keywords: cascading effects, habitat fragmentation, Los Tuxtlas rainforest, species, winner species

\section{A commentary on}

Anthropogenic disturbances jeopardize biodiversity conservation within tropical rainforest reserves

by Martínez-Ramos, M., Ortiz-Rodríguez, I. A., Piñero, D., Dirzo, R., and Sarukhán, J. (2016). Proc. Natl. Acad. Sci. U.S.A. 113, 5323-5328. doi: 10.1073/pnas.1602893113

OPEN ACCESS

Edited by:

James Guy Castley,

Griffith University, Australia

Reviewed by:

Miguel O/vera Vargas

Universidad de Guadalajara, Mexico Kara Lefevre,

Florida Gulf Coast University, USA

${ }^{*}$ Correspondence:

Víctor Arroyo-Rodríguez victorarroyo_rodriguez@hotmail.com

Specialty section:

This article was submitted to

Conservation,

a section of the journal

Frontiers in Ecology and Evolution

Received: 22 April 2016

Accepted: 06 June 2016

Published: 17 June 2016

Citation:

Arroyo-Rodríguez V and Melo FPL (2016) Commentary: Anthropogenic disturbances jeopardize biodiversity conservation within tropical rainforest

reserves. Front. Ecol. Evol. 4:73.

doi: 10.3389/fevo.2016.00073
In the new ecological order where less biodiversity inhabits human-modified landscapes we can split species into "winners" and "losers" (McKinney and Lockwood, 1999). Winner species proliferate in disturbed ecosystems, and can replace loser species through cascading effects (Tabarelli et al., 2012). In their long-term study of Astrocaryum mexicanum populations, MartínezRamos et al. (2016) conclude that habitat fragmentation and defaunation stimulated a demographic explosion of this native understory palm species in the Los Tuxtlas Station (640 ha), Veracruz State, Mexico $\left(18^{\circ} 35^{\prime} 05.7^{\prime \prime} \mathrm{N}, 95^{\circ} 04^{\prime} 30.4^{\prime \prime} \mathrm{W}\right)$, with populations increasing from 1243 to 4058 adult individuals per hectare in 39 year. They argue that "faster gap formation increased understory light availability, enhancing seed production and the growth of immature palms, whereas release from mammalian herbivory and trampling increased survival of seedlings and juveniles" (MartínezRamos et al., 2016, p. 1). They also show, in a very convincingly way, that such demographic explosion of A. mexicanum led to the loss of local (alpha) tree species diversity, turning this palm into a typical winner species within the study area. Based on these findings, the authors argue that such a proliferation of a native palm species driven by anthropogenic disturbances occurring outside the Los Tuxtlas Station threatens biodiversity conservation within this rainforest reserve. We challenge that conclusion as this study is based on only eight relatively small ( 0.06 ha each) and spatially aggregated sampling plots (i.e., they covered an area of approximately $10 \mathrm{ha}$ ). In fact, based on two different studies of $A$. mexicanum populations (see below), we show a very different scenario for this palm species at the regional scale, as we found that A. mexicanum (1) is probably proliferating only in a few areas of the Los Tuxtlas Station; and (2) is rather a loser species in the Los Tuxtlas region as a whole. We therefore advocate for the need of assessing the impact of this and other winner species on biodiversity at a broader landscape or regional scale.

In 2003, we recorded adult individuals of A. mexicanum in ten 0.01-ha plots located randomly in the Los Tuxtlas Station, and found that palm density was highly variable, averaging 900 adult individuals per hectare (range $=400-1700$; Arroyo-Rodríguez et al., 2007). More recently (2015), we recorded 1180 individuals per hectare (range $=400-2200$ ) in 10 different 0.01 -ha plots located in the Los Tuxtlas Station $\left(18^{\circ} 34^{\prime} 41.7^{\prime \prime} \mathrm{N}, 95^{\circ} 05^{\prime} 06.9^{\prime \prime} \mathrm{W}\right)$, but $1 \mathrm{~km}$ away from the plots studied 
by Martínez-Ramos et al. (2016) and Arroyo-Rodríguez et al. (2007). These numbers are similar to those recorded by MartínezRamos et al. (2016) before the demographic explosion of $A$. mexicanum in mid 1970's, and indicate that palm density is quite variable there, depending on gap dynamics and alternative factors not explored by the authors (e.g., topography and aspect). This spatially aggregated pattern of $A$. mexicanum populations may be related to dispersal limitation, as this species has large seeds that are mainly dispersed by gravity (Martínez-Ramos, 1997), although some rodents can act as secondary dispersers, moving seeds up to $15 \mathrm{~m}$ away from the parent plant (Eguiarte et al., 1993).

Outside this station, we also recorded in 2003 all adult palms in 450 plots ( 0.01 ha each) from 45 forest fragments (1-266 ha) distributed through the Los Tuxtlas region (i.e., within three landscapes of 5000 ha each), and found that smaller, and more isolated and irregularly shaped fragments harbor a smaller number of adult individuals of this species (Arroyo-Rodríguez et al., 2007). At the regional scale, palm density was positivelyrather than negatively-correlated with species richness of oldgrowth forest species, but negatively correlated with richness of pioneer species (a proxy of local disturbance; Arroyo-Rodríguez et al., 2007). Therefore, habitat fragmentation has a negative, not positive, impact on A. mexicanum, as this understory palm is a shade-tolerant species that is drastically affected if exposed to the intense solar radiation that characterizes forest edges (Martínez-Ramos, 1997). We therefore argue that rather than being a "winner," A. mexicanum is amongst the several "loser" species that are vanishing as a result of human-caused disturbance.

Patterns and processes linked to negative cascading effects in human-modified landscapes are well known, but researchers must look for them at landscape or regional scales (Fahrig, 2005; Lindenmayer et al., 2008; Fahrig et al., 2011; ArroyoRodríguez et al., 2015). The case study reported by MartínezRamos et al. (2016) demonstrates that when dominant, this

\section{REFERENCES}

Arroyo-Rodríguez, V., Aguirre, A., Benítez-Malvido, J., and Mandujano, S. (2007). Impact of rain forest fragmentation on the population size of a structurally important palm species: Astrocaryum mexicanum at Los Tuxtlas, Mexico. Biol. Conserv. 138, 198-206. doi: 10.1016/j.biocon.2007.04.016

Arroyo-Rodríguez, V., Melo, F. P. L., Martínez-Ramos, M., Bongers, F., Chazdon, R. L., Meave, J. A., et al. (2015). Multiple successional pathways in humanmodified tropical landscapes: new insights from forest succession, forest fragmentation and landscape ecology research. Biol. Rev. Camb. Philos. Soc. doi: 10.1111/brv.12231. [Epub ahead of print].

Arroyo-Rodríguez, V., Rös, M., Escobar, F., Melo, F. P. L., Santos, B. A., Tabarelli, M., et al. (2013). Plant $\beta$-diversity in fragmented rainforests: testing floristic homogenization and differentiation hypotheses. J. Ecol. 101, 1449-1458. doi: 10.1111/1365-2745.12153

Eguiarte, L. E., Búrquez, A., Rodríguez, J., Martínez-Ramos, M., Sarukán, J., and Piñero, D. (1993). Direct and indirect estimates of neighborhood and effective population size in a tropical palm, Astrocaryum mexicanum. Evolution 47, $75-87$. palm, as many other species, can cause severe negative effects on biodiversity at a local scale. Nevertheless, when assessed at the regional scale, we found that this species only dominates plant communities in only some areas of Los Tuxtlas Station and a few large forest fragments. Thus, we do not think that this species jeopardizes biodiversity conservation within Station or the Los Tuxtlas region as a whole. Rather we note that Martínez-Ramos et al. have demonstrated elegantly that this species can shape forest succession, thus contributing to explain, at least partially, the multiple successional pathways that forest patches may follow in human-modified tropical landscapes (Arroyo-Rodríguez et al., 2015 ), and the patterns of plant species turnover ( $\beta$-diversity) within and among fragments in that particular region (ArroyoRodríguez et al., 2013). The main message of Martínez-Ramos et al. must be taken with caution and placed in context at the correct scale, in order to have a better understanding of the patterns and processes driving ecosystem functioning and biodiversity maintenance in forest reserves that are embedded within human-modified landscapes.

\section{AUTHOR CONTRIBUTIONS}

VAR analyzed data; VAR, FPLM conceived and wrote the commentary.

\section{FUNDING}

VAR supported by PAPIIT-DGAPA, UNAM (IN-204215) and CONACyT (project 253946). FPLM supported by CNPq (project 47057420135). We wrote the manuscript while FPLM was on a research stay at the Instituto de Investigaciones en Ecosistemas y Sustentabilidad, UNAM, funded by PAPIIT (IN-204215).

\section{ACKNOWLEDGMENTS}

We thank M. A. Hernández-Ruedas for making his unpublished data available to us.

Fahrig, L. (2005). "When is a landscape perspective important?", in Issues and Perspectives in Landscape Ecology, eds J. A. Wiens and M. R. Moss (Cambridge: Cambridge University Press), 3-10.

Fahrig, F., Baudry, J., Brotons, L., Burel, F. G., Crist, T. O., Fuller, R. J., et al. (2011). Functional landscape heterogeneity and animal biodiversity in agricultural landscapes. Ecol. Lett. 14, 101-112. doi: 10.1111/j.1461-0248.2010.01559.x

Lindenmayer, D., Hobbs, R. J., Montague-Drake, R., Alexandra, J., Bennett, A., Burgman, M., et al. (2008). A checklist for ecological management of landscapes for conservation. Ecol. Lett. 11, 78-91. doi: 10.1111/j.1461-0248.2007.01114.x

Martínez-Ramos, M. (1997). "Astrocaryum mexicanum," in Historia Natural de Los Tuxtlas, eds E. González-Soriano, R. Dirzo, and R. C. Vogt (Mexico City: CONABIO and UNAM), 92-97.

Martínez-Ramos, M., Ortiz-Rodríguez, I. A., Piñero, D., Dirzo, R., and Sarukhán, J. (2016). Anthropogenic disturbances jeopardize biodiversity conservation within tropical rainforest reserves. Proc. Natl. Acad. Sci. U.S.A. 113, 5323-5328. doi: $10.1073 /$ pnas.1602893113

McKinney, M. L., and Lockwood, J. L. (1999). Biotic homogenization: a few winners replacing many losers in the next mass extinction. Trends Ecol. Evol. 14, 450-453. doi: 10.1016/S0169-5347(99)01679-1 
Tabarelli, M., Peres, C. A., and Melo, F. P. L. (2012). The 'few winners and many losers' paradigm revisited: emerging prospects for tropical forest biodiversity. Biol. Conserv. 155, 136-140. doi: 10.1016/j.biocon.2012.06.020

Conflict of Interest Statement: The authors declare that the research was conducted in the absence of any commercial or financial relationships that could be construed as a potential conflict of interest.
Copyright (c) 2016 Arroyo-Rodríguez and Melo. This is an open-access article distributed under the terms of the Creative Commons Attribution License (CC $B Y)$. The use, distribution or reproduction in other forums is permitted, provided the original author(s) or licensor are credited and that the original publication in this journal is cited, in accordance with accepted academic practice. No use, distribution or reproduction is permitted which does not comply with these terms. 